\title{
Genetic traceability of Staphylococcus aureus strains isolated from primiparous dairy cows mastitis, humans and environment in the Northeast region of Brazil
}

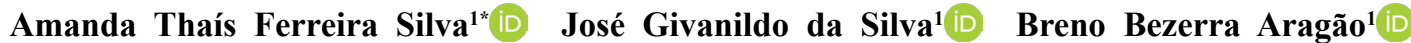 \\ Núbia Michelle Vieira da Silva ${ }^{2}$ (D) Priscylla Carvalho Vasconcelos ${ }^{2}$ (D) \\ Celso José Bruno de Oliveira ${ }^{2}$ iD Rinaldo Aparecido Mota ${ }^{1}$ iD
}

${ }^{1}$ Departamento de Medicina Veterinária, Universidade Federal Rural de Pernambuco (UFRPE), 52171-900, Recife, PE, Brasil. E-mail: amanda.tfs@gmail.com. *Corresponding autor.

${ }^{2}$ Departamento de Zootecnia, Universidade Federal da Paraíba (UFPB), Areia, PB, Brasil.

ABSTRACT: This research aimed to investigate the genotypic relatedness of 18 Staphylococcus aureus strains isolated from intramammary infections in primiparous cows and extramammary sites on five dairy herds by rep-PCR using RW3A primers, and by PFGE using the endonuclease SmaI. The isolates were also evaluated in vitro for the susceptibility against beta-lactam antimicrobials drugs (penicillin and oxacillin), considering that beta-lactams are frequently used for treating staphylococcal intrammamary infections. The rep-PCR typing was highly discriminatory $(D$ value $=0.9804)$ and a total of 15 patterns were detected. The $P F G E$ method was also highly discriminatory $(D$ value $=$ 0.9667) and a total of 13 patterns were observed. A total of 15 out of 18 (83\%) isolates were resistant to penicillin and one out of 18 (6\%) to oxacillin. In conclusion, these findings confirmed the occurrence of a high genetic diversity of S. aureus strains at the herds and the presence of clonally-related strains only at the same herd, emphasizing a variety of genotypic profiles among the isolates. Key words: staphylococcal intramammary infection, DNA fingerprinting, drug resistance, beta-lactam, heifer.

Rastreabilidade genética de cepas de Staphylococcus aureus isoladas de mastite de vacas primíparas, ordenhadores e ambiente de ordenha na região Nordeste do Brasil

RESUMO: Objetivou-se com este estudo investigar a correlação genética de 18 cepas de Staphylococcus aureus isoladas de infecções intramamárias em vacas primíparas e de locais extramamários em cinco propriedades leiteiras através das técnicas de PCR por sequências palindrômicas extragênicas repetitivas (rep-PCR), usando iniciadores $R W 3 A$, e de eletroforese em gel de campo pulsado (PFGE), usando a endonuclease SmaI. Os isolados também foram avaliados in vitro quanto à suscetibilidade aos antimicrobianos beta-lactâmicos (penicilina e oxacilina). A tipagem por rep-PCR foi altamente discriminatória (valor $D=0,9804$ ) e um total de 15 padrões foram detectados. Os isolados de $S$. aureus foram agrupados em três grupos diferentes (A a C), com 80\% de similaridade. A técnica de PFGE também foi altamente discriminatória (valor $D=0,9667)$ e um total de 13 padrões foi observado. A análise do dendrograma com um coeficiente de similaridade de 80\% gerou dois grupos diferentes (A e B). Além disso, cepas clonais isoladas do leite foram identificadas na mesma propriedade pelos dois métodos de tipificação e, apesar da presença de cepas dominantes, nossos resultados sugerem uma alta diversidade genética dentre as cepas de S. aureus analisadas. Um total de 15, dos 18 (83\%) isolados, eram resistentes à penicilina e um dos 18 (6\%) à oxacilina. Assim, esses achados confirmam a ocorrência de uma alta diversidade genética de cepas de S. aureus nas propriedades e a presença de cepas clonalmente relacionadas apenas na mesma propriedade, enfatizando uma variedade de perfis genotípicos entre os isolados.

Palavras-chave: infecção intramamária estafilocócica, impressão digital genética, resistência antimicrobiana, beta-lactâmico, primípara.

\section{INTRODUCTION}

Primiparous dairy cows are of key significance for every dairy herd as their mammary gland health status will directly impact the longevity of the animals and herd productivity. Despite of the common sense that they are not susceptible to intramammary infections (IMIs), an increasing number of recent studies have reported cases of mastitis in primiparous cows, mainly attributed to Staphylococcus spp. (ANDERSON et al., 2012; STALDER et al., 2014; BAŞTAN et al., 2015).
There are still a lot of uncertainties about the epidemiology of these IMIs and Staphylococcus aureus has been considered an important contagious agent transmitted among lactating animals (BAŞTAN et al., 2015). However, previous researches suggest humans and environment as potential sources of $S$. aureus causing mastitis in dairy heifers (STALDER et al., 2014; BAŞTAN et al., 2015). Furthermore, emerging antimicrobial resistance in $S$. aureus has posed a serious problem to the treatment of mastitis in dairy herds (DIAS et al., 2015).

Considering the important role of Staphylococcus aureus on the mastitis etiology 
in primiparous cows, the objective of this study was to investigate the genotypic relatedness of $S$. aureus isolates causing IMIs in dairy heifers and extramammary sites on five dairy herds located in the dairy region of Pernambuco State, Brazil.

\section{MATERIALS AND METHODS}

\section{Sample collection}

The study was conducted on five mediumsized dairy farms $(1,2,3,4$ and 5$)$ in the dairy region of Pernambuco State, Northeastern Brazil (Figure 1), between 2018 and 2019. The number of lactating cows was over 100 cows per farm, including primiparous dairy cows. These five dairy farms had a total of 60 primiparous dairy cows in lactation, being the milk from all those sampled. A total of 240 individual quarter milk samples were aseptically collected from all primiparous dairy cows. Furthermore, samples from primiparous cows' teat skin, dairy environment (mechanical milking equipment) and milkers (nostril and hands) were obtained by using sterile swabs. A total of 60 samples of teat swabs were collected using sterile swabs moistened with sterile saline to swab the teat skin from front and rear teats. Also, 21 samples of teat sets (forming pools of each equipment) were collected in the after milking period using sterile swabs and a total of 16 samples of nostrils $(n=8)$ and hands $(n=8)$ of 8 consenting milkers were sampled in the intermilking period using sterile swabs.

\section{Isolation and preliminary identification of Staphylococcus aureus}

Isolation of Staphylococcus aureus was performed by direct plating of all samples on Mannitol salt agar (Difco Laboratories Inc., Detroit, USA) with 5\% egg yolk (HiMedia, Mumbai, India) and incubated aerobically at $37^{\circ} \mathrm{C}\left( \pm 1^{\circ} \mathrm{C}\right)$ with readings after 24 , and 48 hours to identify colony morphology. Bacteria were isolated and identified by their colony morphology, mannitol fermentation, Gram stain results, and biochemical test results (catalase and coagulase tests) according to NMC (1990) and Quinn et al. (2002). Subsequently, the isolates were subjected to molecular techniques in order to obtain an accurate identification and characterization.

\section{Confirmation of Staphylococcus aureus}

Species confirmation was achieved by Polymerase Chain Reaction (PCR) for amplification of the 279pb nuc gene (KATEETE et al., 2010), using the $\mathrm{ATCC}^{\circledR} 43300 \quad$ S. aureus subspecies aureus strain as a positive control and DNA Free
Water (QIAGEN, Hilden, Germany) as a negative control. Genomic DNA extraction of all isolates was conducted according to MALIK et al., (2007), with modifications. All isolates were grown overnight at $37^{\circ} \mathrm{C}$ on Mannitol Salt Agar (Difco Laboratories Inc., Detroit, USA) enriched with egg yolk emulsion (HiMedia, Mumbai, India), and then an inoculation loop (1-microliter) was used to pick up a sample of each colony and to place each one inside a tube containing $200 \mathrm{~mL}$ of TE buffer to suspend it. The suspension was boiled at $90^{\circ} \mathrm{C}$ for $15 \mathrm{~min}$ and was kept on ice for 30 minutes. After that, the suspension was centrifuged at $13,200 \mathrm{rpm}$ for $5 \mathrm{~min}$ in a centrifuge and the supernatants were kept on ice. Subsequently, DNA concentration and purity were assessed using a spectrophotometer (Thermo Fisher Scientific, Massachusetts, USA) with absorbance at 260nm (BRAKSTAD et al., 1992).

\section{Polymerase Chain Reaction (PCR) testing for beta- lactam resistance genes}

PCR was performed for amplification of blaZ gene, which encodes beta-lactamases, as previously described by SAWANT et al. (2009) and $m e c A$ and $m e c C$ genes, which are inducers of the beta-lactam site of action modification, according to NAKAGAWA et al. (2005) and PATERSON et al. (2012), respectively.

Reactions were assembled separately for each gene in a final volume of $15 \mu \mathrm{L}$ per well, containing 100ng of DNA template, 10pmol of each oligonucleotide (Table 1), Taq buffer (10mM Tris, $50 \mathrm{mM} \mathrm{KCl}, 2.5 \mathrm{mM} \mathrm{MgCl} 2), 200 \mathrm{mM}$ dNTPs and $1 \mathrm{U}$ Taq DNA polymerase (Cenbiot, Taq DNA polymerase, Ludwig Biotec, Porto Alegre, RS, Brazil). Thermal profiles of amplifications were $4 \mathrm{~min}$. at $94{ }^{\circ} \mathrm{C}$, followed by 32 cycles of denaturation at $94{ }^{\circ} \mathrm{C}$ for 30 sec., annealing at $50.5^{\circ} \mathrm{C}$ for $30 \mathrm{sec}$. (blaZ gene) or $55^{\circ} \mathrm{C}$ ( $m e c A$ and $m e c C$ genes) and extended at $72{ }^{\circ} \mathrm{C}$ for $30 \mathrm{sec}$., with final extension at $72{ }^{\circ} \mathrm{C}$ for $5 \mathrm{~min}$. Then $10 \mu \mathrm{L}$ of each reaction was electrophoresed for 40 minutes at $100 \mathrm{~V}$ in $1.5 \%$ agarose gel stained with BlueGreen, visualized and photodocumented under ultraviolet light.

\section{Beta-lactam susceptibility test}

Isolates were suspended in brain-heart infusion (BHI) broth and the suspension was adjusted to a turbidity equivalent to $0.5 \mathrm{McF}$ arland standards. Drug susceptibility testing was performed by Minimum Inhibitory Concentration (MIC) technique using microdilutions of penicillin and oxacillin (CLSI, 2018). Afterwards, the isolates were categorized as 


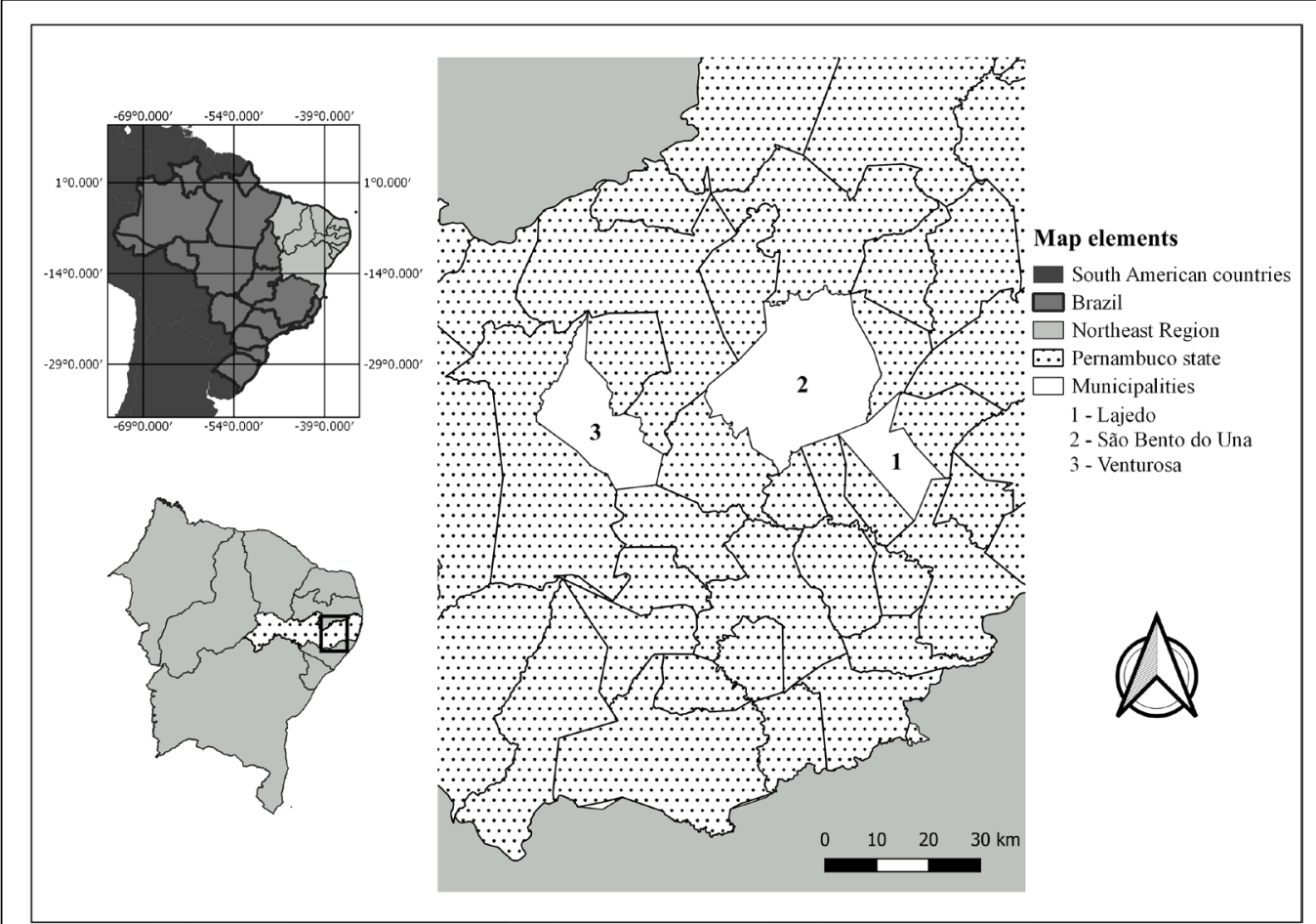

Figure 1 - Distribution map of the municipalities sampled, located in the dairy region of Pernambuco State, Northeastern Brazil.

susceptible, intermediate and resistant based upon interpretative criteria developed by the National Committee of Clinical Laboratory Standards. The ATCC $^{\circledR} 43300$ S. aureus subspecies aureus strain was used as a recommended quality control reference organism to be run with each group of unknowns.
DNA fingerprinting by rep-PCR

Repetitive element palindromicpolymerase chain reaction (rep-PCR) assay was carried out as described by VAN DER ZEE et al.(1999) to identify possible transmission routes of S. aureus among herds. Genomic DNA was extracted

Table 1 - Sequences of the oligonucleotides used in this study and sizes of the amplified fragments, in base pairs (bp).

\begin{tabular}{|c|c|c|c|c|}
\hline Primer & Sequence $\left(5^{\prime}-3^{\prime}\right)$ & Amplicon (bp) & $\begin{array}{l}\text { Thermocycling } \\
\text { conditions }^{\mathrm{a}}\end{array}$ & Reference \\
\hline blaZ & $\begin{array}{l}\text { F-AAGAGATTTGCCTATGCTTC } \\
\text { R-GCTTGACCACTTTTATCAGC }\end{array}$ & 517 & 1 & $\begin{array}{l}\text { Sawant et } \\
\text { al. } 2009\end{array}$ \\
\hline mecA & $\begin{array}{l}\text { F-TGGTATGTGGAAGTTAGATTGGGAT } \\
\text { R-CTAATCTCATATGTGTTCCTGTATTGGC }\end{array}$ & 155 & 1 & $\begin{array}{l}\text { Nakagawa } \\
\text { et al. } 2005\end{array}$ \\
\hline mecC & $\begin{array}{l}\text { F-CATTAAAATCAGAGCGAGGC } \\
\text { R-TGGCTGAACCCATTTTTGAT }\end{array}$ & 188 & 2 & $\begin{array}{l}\text { Paterson et } \\
\text { al. } 2012\end{array}$ \\
\hline
\end{tabular}

${ }^{\mathrm{a}} 1=4 \mathrm{~min}$. at $94{ }^{\circ} \mathrm{C}$, followed by 32 cycles of denaturation at $94{ }^{\circ} \mathrm{C}$ for $30 \mathrm{sec}$, annealing at $50.5^{\circ} \mathrm{C}$ for 30 sec. and extended at $72{ }^{\circ} \mathrm{C}$ for $30 \mathrm{sec}$., with final extension at $72^{\circ} \mathrm{C}$ for $5 \mathrm{~min}$.; $2=4 \mathrm{~min}$. at $94{ }^{\circ} \mathrm{C}$, followed by 32 cycles of denaturation at $94{ }^{\circ} \mathrm{C}$ for 30 sec., annealing at $55^{\circ} \mathrm{C}$ for $30 \mathrm{sec}$. and extended at $72{ }^{\circ} \mathrm{C}$ for $30 \mathrm{sec}$., with final extension at $72{ }^{\circ} \mathrm{C}$ for $5 \mathrm{~min}$.

Ciência Rural, v.51, n.4, 2021. 
(CHAPAVAL et al., 2006) and $25-\mu \mathrm{L}$ reactions contained Taq DNA polymerase buffer (1X), $\mathrm{MgCl} 2$ (3 mM), Taq DNA polymerase (1 U; Invitrogen, USA), dNTPs (200 $\mu \mathrm{M}$ each; Ludwing Biotec, Brazil), primer RW3A (VAN DER ZEE et al., 1999) (1 pMol; Invitrogen, USA), and DNA template (100 ng). Amplification cycles included $1 \mathrm{~min}$ at $94{ }^{\circ} \mathrm{C}, 1$ min at $50{ }^{\circ} \mathrm{C}$, and $2 \mathrm{~min}$ at $72{ }^{\circ} \mathrm{C}$. Amplified products were separated by electrophoresis in a $1.5 \%$ agarose gel in $0.5 \mathrm{X}$ TBE buffer at a constant voltage of $4 \mathrm{~V} / \mathrm{cm}$ and stained using ethidium bromide $(0.5 \mu \mathrm{g} / \mathrm{ml})$. The PCR pattern analysis was performed as was described previously. Dendograms was built by an unweighted pair group method with arithmetic mean clustering algorithm (UPGMA) and the genetic similarity between isolates was calculated using the Jaccard's coefficient ( $1 \%$ tolerance), using BioNumerics ${ }^{\circledR}$ software (Version 7.1, Applied Maths, Belgium).

\section{DNA fingerprinting by PFGE}

Genomic DNA from $2 \mathrm{ml}$ of overnight cultures was prepared in low-melting-point agarose plugs as described by ANDRÉ et al. (2008), and digested with the endonuclease SmaI (New England Biolabs, France) according to the manufacturer's instructions. The PFGE pattern analysis was performed as described by TENOVER et al. (1995). Dendrograms was built by an unweighted pair group method with arithmetic mean clustering algorithm (UPGMA) and the genetic similarity between isolates was calculated using the Dice's coefficient (5\% tolerance), using BioNumerics software (Version 7.1, Applied Maths, Belgium).

\section{Discriminatory power of the typing methods}

The discriminatory power was assessed using the Simpson's index of diversity $(D)$ that indicates the average probability that a typing system will assign a different type to two unrelated strains randomly sampled from a population (HUNTER, 1990).

\section{RESULTS AND DISCUSSION}

In this study, a total of $18 \mathrm{~S}$. aureus strains were obtained from the five dairy farms, named Farm $1(\mathrm{n}=12 ; 11$ from milk and 1 from teat swab), Farm 2 $(\mathrm{n}=1$; from human nostril), Farm $3(\mathrm{n}=1$; from human nostril), Farm 4 ( $n=2 ; 1$ from milk and 1 from human nostril) and Farm $5(n=2 ; 1$ from human hand and 1 from human nostril). All 18 isolates were confirmed to be $S$. aureus by PCR for nuc gene and the presence of the blaZ gene was detected in $100 \%(18 / 18)$ of them; however, mecA and mecC were not detected among the isolates. Considering the antimicrobial susceptibility testing results, approximately $83 \%$ $(15 / 18)$ of the strains were resistant to penicillin and $6 \%(1 / 18)$ to oxacillin.

The detection of blaZ gene in all $S$. aureus isolates was mostly compatible to the phenotypic resistance profiles of penicillin and this usually occurs due to beta-lactamases action, whose production is induced by blaZ gene (DIAS et al., 2015). Also, the high occurrence of blaZ gene is in agreement with a study conducted by KREWER et al. (2015) in the Brazilian Northeast region, strongly suggesting its great epidemiological importance as a mechanism of beta-lactam resistance in staphylococci in dairy herds.

The identification of one $S$. aureus isolate (from milk sample) showing phenotypic resistance to oxacillin and lacking both mecA and mecC genes could be explained by other resistance mechanisms, such as the occurrence of putative homologous genes (MENDONÇA et al., 2012), the production of other classes of Penicillin-binding proteins (MENDONÇA et al., 2012), due to a beta-lactamase hyperproduction (MENDONÇA et al., 2012), or mediated by efflux pumps (JANG, 2016). These mechanisms may be used by the bacteria as a defense strategy, avoiding drug effectiveness and allowing phenotypic resistance.

The rep-PCR method was highly discriminatory $(\mathrm{D}$ value $=0.9804)$ and a total of 15 patterns were observed. The $S$. aureus isolates were grouped in three different clusters (A to C) at $80 \%$ similarity (Figure 2 ). The isolates from human origin were not related to those from animal and environmental sources. Conversely, SILVA et al. (2020) reported the isolation of clonally-related strains of $S$. aureus in milk, milker's hand swabs and milking bucket samples from the same herd. At a $100 \%$ similarity level, most of the isolates showed unique genotypic patterns and only three clusters (I to III) containing clonal isolates were identified. A highly diversity of genotypic patterns were observed among isolates within the same farm. On the contrary, REINOSO et al. (2007) reported that genotypic patterns were similar in the different herds assessed during their study, suggesting a close genetic relationship between herds.

By PFGE, using SmaI as the restriction enzyme, samples 15 and 18, both from human nostrils, could not be lysed. These isolates were; therefore, excluded from the analysis. Furthermore, the PFGE method was highly discriminatory (D value $=0.9667$ ) and a total of 13 patterns were observed. The dendrogram analysis with an $80 \%$ similarity 


$\begin{array}{lllll} & \\ \text { milk }\end{array}$

coefficient generated two different clusters (A and B), all from Farm 1 (Figure 3). At a 100\% similarity level, most of the isolates showed unique genotypic patterns and only two pulsotypes (I and II) containing clonal isolates were identified. The majority of the strains were grouped in pulsotype I. These findings are in agreement with the results reported by GIRARDINI et al., (2016) indicating that $S$. aureus strains are more presumably to be unique to a herd than to be discovered in several herds.

Interestingly, both molecular typing

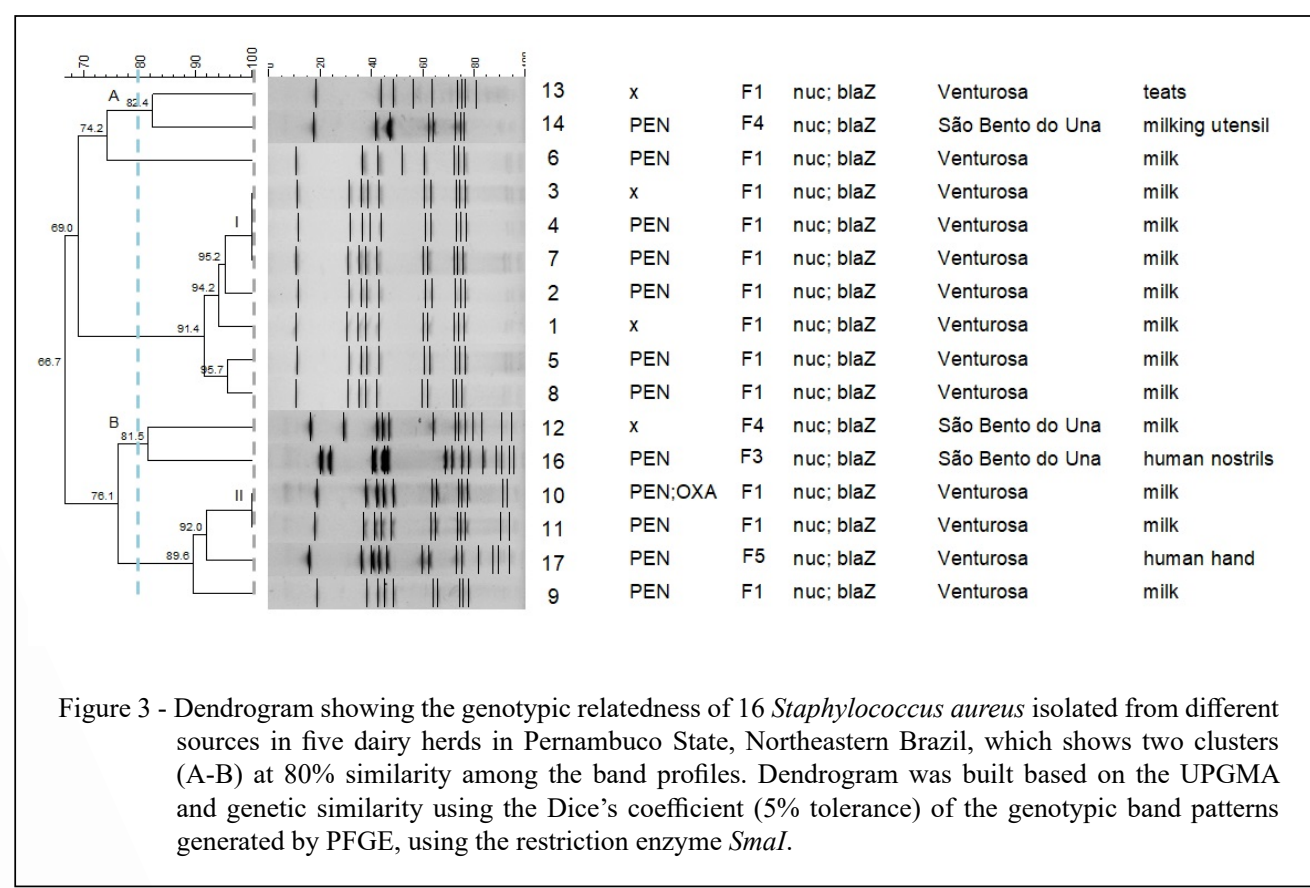

Ciência Rural, v.51, n.4, 2021. 
methods demonstrated quite different genotypic profiles between human and milk samples. Additionally, there was no isolation of $S$. aureus in human sources in the farms with higher mastitis index, and there were no cases of heifer mastitis in the farms with higher isolation of $S$. aureus in human sources. Hence, $S$. aureus isolates associated with heifer mastitis were not of human origin.

Based on the cluster analysis, clonallyrelated strains isolated from milk were identified at the same farm (Farm 1) by both typing methods, and despite the presence of dominant strains, our results suggested a high genetic diversity of $S$. aureus strains exist at the farms. This is in concordance with recent studies that showed genetically diverse and heterogeneous $S$. aureus strains isolated from bovine, environment and humans (KÜMMEL et al., 2016; PAPADOPOULOS et al., 2018).

No agreement between antimicrobial patterns, rep-profiles and PFGE-profiles was observed for the majority of the isolates in this study, which is in consonance with the results of REINOSO et al. (2007) and LI et al. (2009). Therefore, beta-lactam resistance patterns alone were reported to be of limited value in differentiating closely related strains.

These findings revealed a significant diversity within the strain collection using repPCR and PFGE typing methods. Thus, the rep-PCR technique is a useful method for the epidemiologic characterization of $S$. aureus, the results being comparable to those obtained with the PFGE technique, both with a high discriminatory power.

All these observations open new perspectives for detailed knowledge on the epidemiology of intramammary infections in primiparous cows caused by $S$. aureus, which might help in creating new approaches to reduce infection spread. Also, a better knowledge of drug-resistant $S$. aureus strains distribution in dairy herds might help in formulating strategies to control of infection.

\section{CONCLUSION}

This report clearly demonstrates the occurrence of a high genetic diversity of $S$. aureus strains at the herds and the presence of clonallyrelated strains only at the same herd, emphasizing a variety of genotypic profiles among the isolates.

\section{ACKNOWLEDGEMENTS}

This work was supported by Fundação de Amparo e Pesquisa do Estado de Pernambuco (FACEPE, process number 0500-5.05/17) and by Coordenação de Aperfeiçoamento de Pessoal de Nível Superior - Brazil (CAPES, financing code 001).

\section{DECLARATION OF CONFLICTS OF INTERESTS}

The authors declare no conflict of interest. The founding sponsors had no role in the design of the study; in the collection, analyses, or interpretation of data; in the writing of the manuscript, and in the decision to publish the results.

\section{AUTHORS' CONTRIBUTIONS}

All authors critically revised the manuscript and approved of the final version.

\section{BIOETHICS AND BIOSSECURITY COMMITTEE APPROVAL}

The experimental procedures were approved by the Ethics Committee on the Use of Animals (CEUA) of Federal Rural University of Pernambuco (UFRPE), Recife, Brazil (License No. 037/2018) and to the Human Research Ethics Committee at University of Pernambuco (UPE), Recife, Brazil (License No. 88030518.0.0000.5207).

\section{REFERENCES}

ANDRÉ, M. C. D. P. B. et al. Comparison of Staphylococcus aureus isolates from food handlers, raw bovine milk and Minas Frescal cheese by antibiogram and pulsed-field gel electrophoresis following SmaI digestion. Food Control, v.19, p.200-207, 2008. Available from: $<$ https://doi.org/10.1016/j.foodcont.2007.03.010>. Accessed: Jan 1, 2020. doi: 10.1016/j.foodcont.2007.03.010.

ANDERSON, K. L. et al. Molecular epidemiology of Staphylococcus aureus mastitis in dairy heifers. Journal of Dairy Science, n.95, p.4921-4930, 2012. Available from: $<$ https://doi. org/10.3168/jds.2011-4913>. Accessed: Jan 5, 2020. doi: 10.3168/ jds.2011-4913.

BAŞTAN, A. et al. The prediction of the prevalence and risk factors for subclinical heifer mastitis in Turkish dairy farms. Turkish Journal of Veterinary and Animal Sciences, v.39, p.682-687, 2015. Available from: <htts://doi.org/10.3906/vet-1501-80>. Accessed: Jan. 10, 2020. doi: 10.3906/vet-1501-80.

BRAKSTAD, O. G. et al. Detection of Staphylococcus aureus by polymerase chain reaction amplification of the nuc gene. Journal of Clinical Microbiology, v.30, p.1654-1660, 1992. Available from: <https://pubmed.ncbi.nlm.nih.gov/1629319/>. Accessed: Jan. 10, 2020 .

Clinical and Laboratory Standards Institute (CLSI) Performance Standards for Antimicrobial Susceptibility Testing, TwentyFifth Informational Supplement, M100-S25. Pennsylvania, USA: CLSI, 2015. Available from: <https:/www.facm.ucl.ac.be/ intranet/CLSI/CLSI-2015-M100-S25.unlocked.pdf>. Accessed: Jan. 9, 2020.

CHAPAVAL, L. et al. Using the REP-PCR technic in the tracking of Staphylococcus aureus in milking room, for milk quality production. Brazilian Journal of Veterinary Research and Animal Science, v.43, n.3, p.309-320, 2006. Available from: $<$ htts:// doi.org/10.11606/issn.1678-4456.bjvras.2006.26478>. Accessed: Jan. 10, 2020. doi: 10.11606/issn.1678-4456.bjvras.2006.26478. 
DIAS, A. P. M. et al. Clinical characteristics, resistance and virulence factors in Staphylococcus aureus. Acta Scientiarum Technology, v.3, p.9-23, 2015. Available from: <https://doi. org/10.1017/S0950268816001552>. Accessed: Jan. 8, 2020. doi: $10.1017 / \mathrm{S} 0950268816001552$

GIRARDINI, L. K. et al. Antimicrobial resistance profiles of Staphylococcus aureus clusters on small dairy farms in southern Brazil. Pesquisa Veterinária Brasileira, v.36, n.10, p.951956, 2016. Available from: <https://doi.org/10.1590/S0100736X2016001000006>. Accessed: Jul. 20, 2020. doi: 10.1590/ S0100-736X2016001000006.

HUNTER, P. Reproducibility and indices of discriminatory power of microbial typing methods. Journal of Clinical Microbiology, v.28, p.1903-1905, 1990. Available from: <https://pubmed.ncbi. nlm.nih.gov/2229371/>. Accessed: Jan. 12, 2020.

JANG, S. Multidrug efflux pumps in Staphylococcus aureus and their clinical implications. Journal of Microbiology, v.54, n.1, p.1-8, 2016. Available from: <https://doi.org/10.1007/s12275016-5159-z>. Accessed: Jan. 10, 2020. doi: 10.1007/s12275-0165159-z.

KATEETE, D. P. et al. Identification of Staphylococcus aureus: DNase and Mannitol salt agar improve the efficiency of the tube coagulase test. Annals of Clinical Microbiology and Antimicrobials, v.9, p.23-29, 2010. Available from: <https:// doi.org/10.1186/1476-0711-9-23>. Accessed: Jan. 7, 2020. doi: $10.1186 / 1476-0711-9-23$

KREWER, C. C. et al. Resistance to antimicrobials and biofilm formation in Staphylococcus spp. isolated from bovine mastitis in the Northeast of Brazil. Tropical animal health and production, v.47, p.511-518, 2015. Available from: < https://doi.org/10.1007/ s11250-014-0752-9>. Acessed: Jan. 6, 2020. doi: 10.1007/s11250014-0752-9

KÜMMEL, J. et al. Staphylococcus aureus entrance into the dairy chain: tracking $S$. aureus from dairy cow to cheese. Frontiers in microbiology, v.7, p.1603, 2016. Available from: <https://doi. org/10.3389/fmicb.2016.01603>. Accessed: Jan. 10, 2020. doi: 10.3389/fmicb.2016.01603

LI, J. et al. Prevalence, genetic diversity, and antimicrobial susceptibility profiles of Staphylococcus aureus isolated from bovine mastitis in Zhejiang Province, China. Journal of Zhejiang University Science B, v.10, n.10, p.753-760, 2009. Available from: < https://doi.org/10.1631/jzus.B0920072>. Acessed: Jan. 10, 2020. doi: 10.1631/jzus.B0920072.

MALIK, S. et al. Presence and diversity of the $\beta$-lactamase gene in cat and dog staphylococci. Veterinary Microbiology, v.123, p.162-168, 2007. Available from: <https://doi.org/10.1016/j. vetmic.2007.02.012>. Acessed: Jul. 12, 2020. doi: 10.1016/j. vetmic. 2007.02 .012

MENDONÇA, et al. Phenogenotypical characterization of antimicrobial resistance in Staphylococcus spp. isolated from bovine mastitis. Pesquisa Veterinária Brasileira, v.32, p.859864, 2012. Available from: <https://doi.org/10.1590/S0100-
736X2012000900008>. Accessed: Jul. 12, 2020. doi: 10.1590/ S0100-736X2012000900008.

NAKAGAWA, T. et al. Cyclophilin D-dependent mitochondrial permeability transition regulates some necrotic but not apoptotic cell death. Nature, v.434, p.652-658, 2005. Available from: $<$ https://doi.org/10.1038/nature03317>. Accessed: Jan. 3, 2020. doi: $10.1038 /$ nature 03317 .

PAPADOPOULOS, P. et al. Prevalence of Staphylococcus aureus and of methicillin-resistant $S$. aureus (MRSA) along the production chain of dairy products in north-western Greece. Food microbiology, v.69, p.43-50, 2018. Available from: $<$ https://doi. org/10.1016/j.fm.2017.07.016>. Accessed: Jan. 10, 2020. doi: 10.1016/j.fm.2017.07.016.

PATERSON, G. K. et al. The newly described mecA homologue, mecALGA251, is present in methicillin-resistant Staphylococcus aureus isolates from a diverse range of host species. Journal of Antimicrobial Chemotherapy, v.67, p.2809-2813, 2012 Available from: <https://doi.org/10.1093/jac/dks329>. Accessed: Jan. 10, 2020. doi: 10.1093/jac/dks329.

REINOSO, E. et al. rep-PCR of Staphylococcus aureus strains isolated from bovine mastitis in Argentina. Brazilian Journal of Veterinary Research and Animal Science, v.4, p.115-121, 2007. Available from: <https://doi.org/10.11606/issn.1678-4456. bjvras.2007.26599>. Accessed: Aug. 20, 2020. doi: 10.11606/ issn.1678-4456.bjvras.2007.26599.

SAWANT, A. et al. Antimicrobial susceptibility of coagulasenegative Staphylococcus species isolated from bovine milk. Veterinary Microbiology, v.134, p.73-81, 2009. Available from: $<$ https://doi.org/10.1590/S0102-09352008000100041>. Accessed: Jan. 2, 2020. doi: 10.1590/S0102-09352008000100041.

STALDER, U. et al. Short communication: Staphylococcus aureus isolated from colostrum of dairy heifers represent a closely related group exhibiting highly homogeneous genomic and antimicrobial resistance features. Journal of Dairy Science, v.97, p.4997-5000, 2014. Available from: <https://doi.org/10.3168/jds.2013-7721> Accessed: Jan. 12, 2020. doi: 10.3168/jds.2013-7721.

SILVA, J. G. et al. First report of a livestock-associated methicillinresistant Staphylococcus aureus ST126 harboring the mecC variant in Brazil. Transboundary and Emerging Diseases, v.1, p.17, 2020. Available from: <https://doi.org/10.1111/tbed.13771>. Accessed: Sep. 12, 2020. doi: 10.1111/tbed.13771.

TENOVER, F. C. et al. Interpreting chromosomal DNA restriction patterns produced by PFGE: criteria for bacterial strain typing. Journal of Clinical Microbiology, v.33, p.2233, 1995. Available from: <https://pubmed.ncbi.nlm.nih.gov/7494007/>. Accessed: Jan. 11, 2020

VAN DER ZEE, A et al. Molecular genotyping of Staphylococcus aureus strains: comparison of repetitive element sequencebased PCR with various typing methods and isolation of a novel epidemicity marker. Journal of Clinical Microbiology, v.37, p.342-349, 1999. Available from: <http://www.ncbi.nlm.nih.gov/ pmc/articles/pmc84303/>. Acecssed: Jan. 13, 2020. 